\title{
PREDIKSI PENJUALAN BIBIT IKAN AIR TAWAR PADA IBAT PANDAAN MENGGUNAKAN METODE TREND MOMENT
}

\author{
Miftachul Ilmi, Ali Mahmudi, Yosep Agus Pranoto \\ Program Studi Teknik Informatika S1, Fakultas Teknologi Industri \\ Institut Teknologi Nasional Malang, Jalan Raya Karanglo km 2 Malang, Indonesia \\ miftachulilmi404@gmail.com
}

\begin{abstract}
ABSTRAK
Pandaan merupakan salah satu kecamatan dalam wilayah Kabupaten Pasuruan. Letaknya sangat strategis, berada di tengah-tengah jalur Surabaya-Malang dengan akses menuju tempat pariwisata yang banyak. Sehingga banyak rumah makan menyajikan ikan bakar dan ayam bakar sebagai menu utama yang disajikan. Menu ikan bakar (khususnya ikan gurame dan ikan nila) menjadi sangat populer dikalangan para wisatawan yang datang ke pandaan, tercatat penjualan pada Ibat pandaan tahun 2015 menunjukkan bahwa total penjualan ikan konsumsi mencapai 4.460 ekor (DKP:2015). Diantaranya penjualan ikan gurame mencapai 464 ekor dan ikan nila 486 ekor.

Sistem yang akan dibangun yaitu sebuah sistem prediksi penjualan bibit ikan air tawar pada Instalasi Budidaya Bibit Ikan Air Tawar pandaan, aplikasi ini dibuat berbasis website dengan hasil pengujian fungsional yang dilakukan menggunakan 3 browser yaitu Google Chrome, Mozilla Firefox dan UC Browser memiliki hasil sesuai harapan.

Penerapan dari hasil prediksi penjualan yang dilakukan menunjukan bahwa hasil prediksi menggunakan metode Trend Moment menghasilkan angka penjualan bibit ikan untuk tahun berikutnya, data tersebut didapat dari proses pencarian nilai trend dengan tingkat kesalahan sistem mencapai 19\%, hal ini disebabkan oleh tingginya angka penambahan data baru melebihi angka penjualan tahun lalu hingga 50\%. Oleh karena itu perlu penambahan metode untuk mendapatkan data prediksi yang lebih akurat karena hasil prediksi menggunakan metode trend momend masih diatas $10 \%$.
\end{abstract}

Kata Kunci :Prediksi Penjualan Bibit Ikan,Trend Moment, Kota Pandaan.

\section{PENDAHULUAN}

Pandaan merupakan salah satu kecamatan dalam wilayah Kabupaten Pasuruan. Letaknya sangat strategis, berada di tengah-tengah jalur SurabayaMalang dengan akses menuju tempat pariwisata yang banyak. Pandaan juga termasuk kawasan pegunungan yang memiliki banyak wisata alami dan pemandangan alam sekitar yang indah, hal ini menjadi pilihan terfavorit bagi wisatawan untuk menikmati suasana sekitar yang masih alami, kondisi suasana daerah pandaan yang relatif dingin, sehingga banyak rumah makan menyajikan ikan bakar dan ayam bakar sebagai menu utama yang disajikan. Menu ikan bakar (khususnya ikan gurame dan ikan nila ) menjadi sangat populer dikalangan para wisatawan yang datang ke pandaan, tercatat penjualan pada Ibat pandaan tahun 2015 menunjukkan bahwa total penjualan ikan konsumsi mencapai 4.460 ekor (DKP:2015). Diantaranya penjualan ikan gurame mencapai 464 ekor dan ikan nila 486 ekor.

Sementara ini stok ikan konsumsi yang di hasilkan dari pihak peternak ikan belum bisa memenuhi permintaan pasar, masalah tersebut disebabkan oleh minimnya stok bibit ikan yang digunakan untuk proses pembesaran ikan, beberapa bibit ikan air tawar seperti ikan gurame dan ikan nila hanya bisa dibeli pada Instalasi Budidaya Air Tawar
(IBAT) Pandaan, masalah ini dipersulit karena proses pembesaran ikan memerlukan waktu yang cukup lama antara 3-5 bulan untuk menjadi ikan yang siap jual.

Oleh karena itu penulis membuat sebuah sistem prediksi penjualan bibit ikan air tawar pada IBAT pandaan, aplikasi ini bertujuan untuk meminimalisir terjadinya kehabisan stok bibit ikan konsumsi terutama pada ikan gurame dan ikan nila, aplikasi ini juga dapat memberikan informasi tentang stok bibit ikan yang masih bisa dibeli, sehingga bagi masyarakat umum dapat membantu mengambil keputusan untuk pemilihan bibit ikan yang akan dibudidayakan sebagai ikan konsumsi.

\section{TINJAUAN PUSTAKA \\ 2.1 Penelitian Terdahulu}

Beberapa keterkaitan penelitian yang di lakukan sebelumnya dari penelitian Imam Wahyudi pada tahun 2016 yang berjudul "Penerapan Metode Trend Moment Untuk Peramalan Penjualan Sepatu dan Sandal Pada Toko BATT". Saat ini Toko BATT setiap harinya konsumen yang membeli di Toko BATT meningkat, dengan melonjaknya peninkatan konsumen pihak dari Toko BATT ingin memperkirakan persediaan stok dan penjualan barang di bulan dan tahun berikutnya. Dengan adanya metode trend moment dapat mengatasi permasalahan, 
sehingga pengaruh unsur subyektif dalam menentukan peramalan penjualan dapat dihindari dan mampu membantu pelaku bisnis untuk menentukan banyaknya persediaan stok barang di bulan berikutnya. [1]

Kemudian Penelitian yang dilakukan Rudy Ariyanto, Odithya Desta Triswidrananta dan Bagas Rukma Pangestu tahun 2020 mengenai pentingnya untuk menjaga suatu persediaan dalam suatu badan usaha terlebih lagi dalam bidang pengobatan, Untuk menjaga stabilitas persediaan stok, maka dibutuhkan suatu peramalan persediaan obat khususnya obat ktonis. Hal ini dapat membantu pimpinan apoteker untuk mengelola usahanya sehingga dapat menyediakan obat-obatan sedini mungkin dan menghindari terjadinya kelebihan obat maupun kekurangan stok [2]

Selanjutnya penelitian dilakukan oleh Dr. Kusrini, M.kom dan Dias Ayu Budi Utami tahun 2016 yang berjudul "Rancang Bangun Peramalan Penjualan Dan Pengendalian Persediaan Beras Menggunakan Metode Trend Moment". Permasalahan yang umum dihadapi adalah bagaimana meramalkan penjualan barang di masa mendatang berdasarkan data yang telah direkam sebelumnya. Peramalan tersebut sangat berpengaruh terhadap keputusan untuk menentukan jumlah produksi yang kemudian mempengaruhi jumlah persediaan barang yang ada di gudang. Maka dari itu dibutuhkan sistem peramalan penjualan barang yang berguna untuk merencanakan jumlah barang yang harus disediakan/diproduksi untuk persediaan di masa mendatang. [3]

Kemudian penelitian yang dilakukan oleh Nurul Fuad dan Eko Sulistiono tahun 2016 yang berjudul "Prediksi Penjualan Kerudung Rabbani Di Griya Muslim Store Dukun Gresik Dengan Trend Moment ". Secara umum proses pengambilan keputusan terdiri dari tiga tahap utama yaitu pengumpulan data atau informasi, pengolahan data atau informasi dan penyimpanan dari data atau informasi yang telah diproses tersebut. Sebuah keputusan yang tepat akan memberikan peningkatan efisiensi dan efektifitas kerja, sumber daya, waktu dan keuntungan bagi perusahaan..[4]

Kemudian penelitian yang dilakukan oleh Siti Mujilahwati, Nur Qomariyah Nawafilah dan Muhammad Aliyudin tahun 2019 yang berjudul "Analisis Hasil Prediksi Dengan Metode Promethee", Hampir setiap sekolah di Indonesia memiliki program beasiswa bagi siswa-siswi baik untuk beasiswa prestasi maupun beasiswa tidak mampu. Setiap sekolah memiliki kreteria tersendiri untuk menentukan penerima beasiswanya. Kreteria tersebut biasanya dilampiri bukti-bukti berkas sebagai bukti secara administrative.[5]

\subsection{Data Mining}

Data mining adalah teknik untuk menganalisa sebuah pola data dari big database yang bertujuan untuk mengidentifikasi dan memilah informasi sesuai dengan kebutuhan yang akan diolah kembali dengan metode tertentu untuk mencapai suatu kesimpulan yang akan digunakan sebagai solusi untuk memecahkan malasah yang dihadapi.

Perkembangan teknologi internet dari tahun ketahun semakin pesat sehingga internet sudah menjadi bagian kehidupan sehari-hari, dengan layanan yang mampu menyediakan informasi dan berbagai fasilitas seperti email, chating, teleconference dan lain sebagainya. sistem data mining yang digunakan sebagai wadah untuk proses pencarian sebuah solusi, dengan menggunakan salah satu fungsi data mining yakni predictive dan hasilnya akan ditampilkan pada sebuah web dan dapat diakses melalui internet.

Salah satu fungsi dari data mining yaitu predictive berguna untuk mencari sebuah pola tertentu dari sebuah data, pola tersebut didapat dari variable-variabel yang sudah ada pada data yang diteliti, pola yang didapat dapat diproses kembali untuk memprediksi suatu kejadian yang akan terjadi di masa depan sehingga fungsi ini meminimalisir efek yang ditimbulkan dari kejadian yang akan datang secara akurat

\subsection{Instalasi Budidaya Air Tawar}

Instalasi Budidaya Air Tawar (disingkat IBAT) merupakan salah satu tempat pembudidayaan, perawatan dan pembesaran ikan air tawar yang meliputi ikan gurame, ikan koi, ikan patin dan udang, Pembudidayaan ikan air tawar pada IBAT pandaan ini menggunakan cara perawatan kolam yang sangat di perhatikan, perawatan tersebut meliputi penggantian air secara rutin dan pemberian makan secara teratur, tidak hanya melakukan pembudidayaan ikan tetapi IBAT pandaan juga melakukan pengembangan induk ikan yang menghasilkan bibit dan telur ikan yang berkualitas.

\subsection{Bibit Ikan Air Tawar}

Pemilihan bibit ikan unggulan merupakan salah satu faktor suksesnya dalam bisnis pembudidayaan ikan, untuk mendapatkan bibit ikan unggulan tentunya memerlukan cara yang tidak mudah, mulai dari pemeliharaan induk ikan, perawatan kolam, pemberian pakan secara teratur, pemberian vitamin untuk meninggkatkan kualitas telur yang dihasilkan. Cara- cara tersebut memerlukan waktu cukup lama karena proses pemilihan induk yang produktif memerlukan usia induk ikan minimal 2 tahun keatas untuk bisa menghasilkan telur yang berkualitas karena semakin tua umur indukan ikan maka akan semakin bagus telur yang dihasilkan.

Menurut nano sudarsono, Nanang Suciyono dan Riyan hardianto (2016), mengatakan bahwa dalam bidang budidaya perikanan juga tidak lepas dari masalah yang mengharuskan setiap orang terlibat didalamnya,Permasalhan kerap dialami dalam penentuan jenis ikan yang cocok untuk 
dibudidayakan pada kondisi atau keadaan daerah tertentu, hal ini akan memperngaruhi kualitas air di masing-masing daerah. [6]

\subsection{Trend Moment}

Penerapan metode trend moment bisa dilakukan dengan menggunakan data historis dari satu variable. Adapun rumus yang digunakan untuk mengolah metode ini menurut Sugiarto dan Dergibson (2002) yakni : [7]

Penjelasan :

$$
\mathrm{Y}=\mathrm{a}+\mathrm{bX} \quad \text { Persamaan }(2.1)
$$

$\mathrm{Y}=$ nilai trend yang digunakan untuk peramalan

$\mathrm{a}=$ bilangan konstan

$\mathrm{b}=$ slope atau koefesien garis trend

$\mathrm{X}=$ index waktu (mulai dari $0,1,2, \ldots$ )

Metode Trend Moment berbeda dengan metode lainnya, penentuan data historis $\mathrm{X}$ pada penggunaannya tidak harus berjumlah genap atau ganjil, karena nilai parameter $\mathrm{X}$ selalu dimulai dengan nilai 0 sebagai urutan yang pertama.

Untuk mencari nilai a pada rumus diatas, menggunakan cara matematis dengan penyelesaian menggunakan subtitusi dan metode eliminasi, adapun persamaannya sebagai berikut :

$$
\begin{aligned}
& \mathrm{b}=\frac{\mathrm{n}\left(\sum \mathrm{xy}\right)-\left(\sum \mathrm{x}\right)\left(\sum \mathrm{y}\right)}{\left(\sum \mathrm{x}^{2}\right)-\left(\sum \mathrm{x}\right)^{2}} \\
& \mathrm{a}=\sum \mathrm{y}-\mathrm{b}\left(\sum \mathrm{x}\right)
\end{aligned}
$$

Persamaan (2.2)

Penjelasan :

$\sum \mathrm{y}=$ jumlah dari data penjualan

$\sum \mathrm{x}=$ jumlah dari periode waktu

$\sum x y=$ jumlah data penjualan dikali dengan periode waktu

$\mathrm{n} \quad=$ jumlah data

Hasil nilai ramalan yang telah diperoleh dari peramalan metode Trend Moment akan dikoreksi terhadap pengaruh musiman dengan menggunakan indeks musim :

Persamaan (2.3)

Indeks musim $=\frac{\text { rata-rata permintaan bulan tertentu }}{\text { Rata-rata permintaan bulanan }}$

Hasil ramalan akhir setelah dipengaruhi oleh indeks musim maka akan menggunakan perhitungan sebagai berikut:

Persamaan (2.4)

$$
\mathrm{y} *=\text { index musim } \mathrm{x} Y
$$

Penjelasan :

$\mathrm{Y}^{*}=$ hasil ramalan dengan menggunakan metode trend moment yang telah dipengaruhi oleh index musim.

$\mathrm{Y}=$ hasil ramalan yang dihasilkan dari metode trend moment

\subsection{XАMPP}

XAMPP adalah salah satu program aplikasi web database yang berguna untuk tempat penyimpanan data secara offline, umumnya para pengembangan menggunakan XAMPP untuk membuat sebuah website berbasis PHP dan MySQL, hal ini dikarenakan program didalam XAMP dapat menunjang pembuatan web server secara mudah dan fleksibel, karena data yang disimpan didalam database XAMP mudah untuk dirubah, kemudahan ini ditunjang dengan adanya dua metode peubahan data yakni dengan mode GUI dan text, Software XAMPP dibuat dan dikembangkan oleh Apache Friends. [8]

\subsection{PHP}

PHP diciptakan oleh Rasmus Lerdorf pertama kali tahun 1994. Pada awalnya PHP adalah singkatan dari Personal Home Page selanjutnya diganti dengan FI (Form Interpreter). Sejak versi 3.0 nama bahasa ini diubah menjadi PHP (Hypertext Preprcessor). Sintak PHP mirip dengan bahasa Perl dan C. PHP biasanya sering digunakan bersama webserverAppache di beragam sistem operasi. PHP juga men-support ISAPI dan dapat digunakan bersama dengan Microsoft IIS di Windows. [9]

\subsection{MySQL}

MySQL adalah salah satu database server cukup dikenal saat ini yang dibuat oleh perusahaan swedia yaitu MYSQL AB. Secara umum MySQL adalah sebuah aplikasi open source yang menangani sistem manajemen database dan sistem manajemen database relational. Setiap pengguna MySQL diizinkan untuk mengubah source untuk keperluan pengembangan atau menyelaraskan spesifikasi database sesuai kebutuhan. [10]

\subsection{Data Sampling}

Data Sampling adalah data yang digunakan untuk proses perhitungan trend moment, data sampling juga termasuk bagian dari metodologi statistika yang berhubungan dengan prosedur sistematis dalam pengambilan sebagian anggota populasi untuk keperluan pradugaan (estimasi).

Berikut ini adalah contoh data sampling total penjualan bibit ikan air tawar pada IBAT pandaan berdasarkan statistika penjualan tahun 2015, data tersebut didapat dari website Dinas Kelautan dan Perikanan jawa timur seperti pada gambar 2.1 dibawah ini :

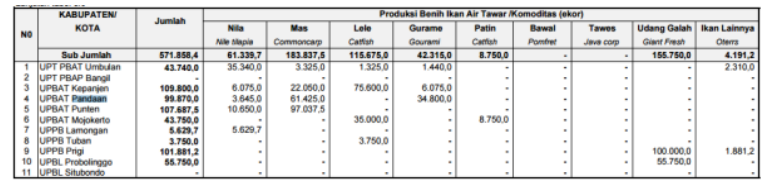

Gambar 2.1 Data penjualan ikan konsumsi 
Pada gambar 2.1 menunjukkan bahwa total penjualan benih ikan air tawar pada Instalasi Budidaya Air Tawar pandaan, data tersebut antara lain bibit ikan nila 3.645 ekor dan bibit ikan gurami 34.800 ekor.

\section{METODE PENELITIAN}

\subsection{Blok Diagram Sistem}

Diagram block adalah diagram sebuah alur sistem yang menjelaskan tentang hubungan antar sistem, setiap fungsi diwakili dengan blok yang saling terhubung seperti Gambar 1.

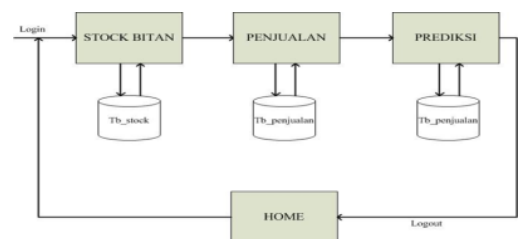

Gambar 1 Blok diagram sistem

\subsection{Struktur Menu}

Menampilkan informasi semua tampilan menu yang ada pada sistem, baik struktur menuuser maupun struktur menu admin

\subsection{Struktur Menu User}

Tampilan semua informasi dari struktur menu yang berada pada posisi user seperti Gambar 2 .

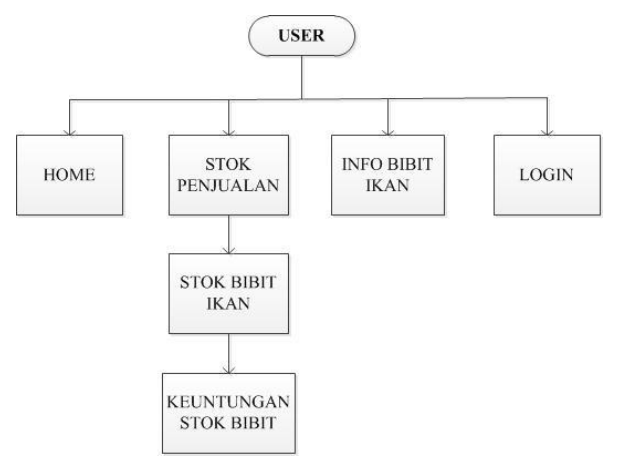

Gambar 2 Menu User

\subsection{Struktur Menu Admin}

Tampilan semua informasi dari struktur menu yang berada pada posisi user seperti Gambar 3.

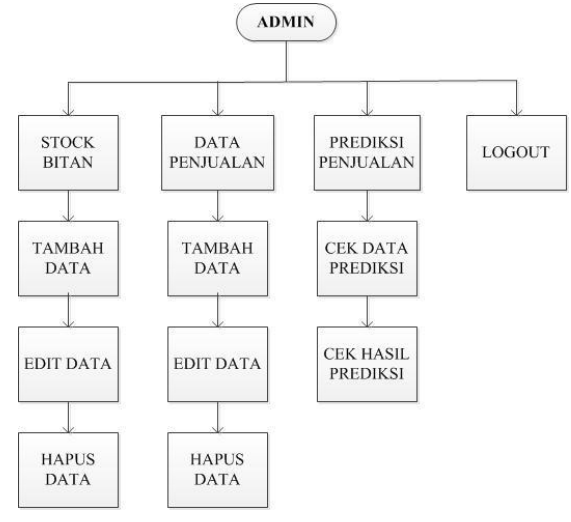

Gambar 3. Menu Admin

\subsection{DFD (Data Flow Diagram)}

Data flow diagram (DFD) dapat digunakan untuk mengambarkan analisa maupun rancangan sistem yang mudah digunakan. Dalam rancangan sistem yang penulis gunakan adalah DFD Level 0. Perancangan DFD sistem adalah sebagai berikut :

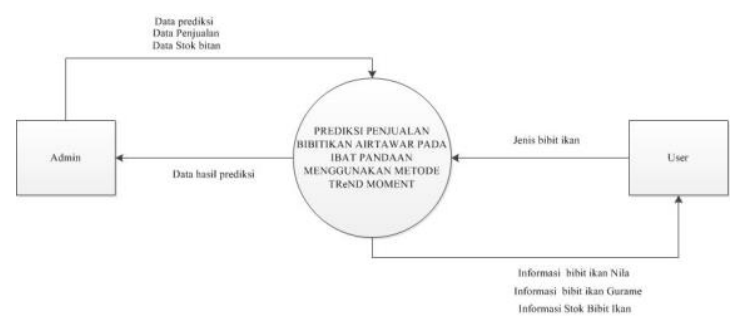

Gambar 4 DFD level 0

DFD Level 0 diperlihatkan pada Gambar 4, dari gambar tersebut menjelaskan tentang perancangan DFD Level 0. Terdapat dua entitas, yaitu user dan admin. User dapat mengakses informasi stok bibit ikan, informasi bibit ikan nila dan informasi bibit ikan Gurame. Sedangkan Admin, dapat memasukkan data stok bibit ikan, data penjualan data prediksi dan data hasil prediksi penjualan.

\subsection{DFD Level 1}

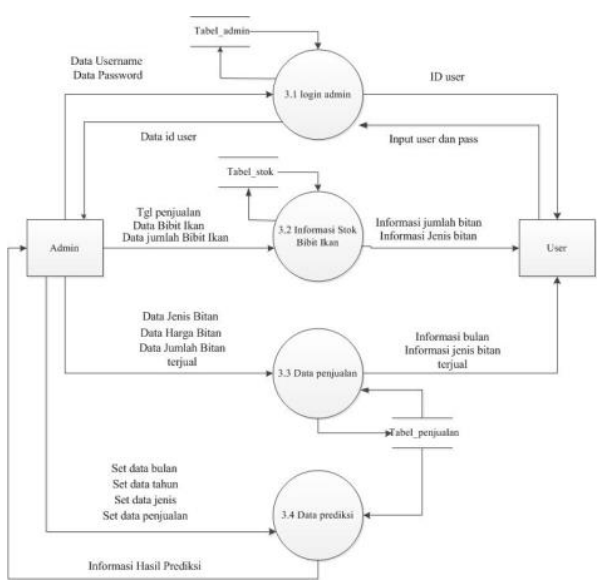

Gambar 5 DFD Level 1 
DFD Level 1 diperlihatkan pada Gambar 5 Terdapat dua entitas, yaitu user dan admin. User hanya bias mengakses informasi stok bibit ikan dan informasi bibit ikan terjual berdasarkan jenis dan bulan, user juga bisa melakukan login admin jida sudah mempunyai username dan password untuk bias masuk kedalam menu admin. Sedangkan admin dapat mengatur data stok bibit ikan mulai dari menambah data baru, menghapus data dari stok dan juga mengedit data stok bibit ikan, admin juga bisa menggunakan fitur prediksi penjualan dengan menggunakan data penjualan yang sudah ada pada database.

\subsection{Flowchart Sistem}

Flowchart sistem ini menjelaskan tentang proses berjalananya aplikasi dari halaman user sampai dengan halaman admin sesuai dengan alur yang dibuat seperti ditunjukkan pada Gambar 6 .

Flowchart pada gambar 6 dimulai dari halaman Home kemudian user akan memilih apakah ke menu login atau tidak, jika yam akan dialihkan ke proses login untuk ke dashboard, didalam dashboard ada beberapa menu yang tersedia yakni menu tambah data stock bitan, menu penjualan bitan dan menu prediksi penjualan, didalam menu prediksi terdapat pemilihan data untuk prediksi berdasarkan jenis bibit ikan, setelah proses prediksi selesai maka akan ditampilkan data hasil dari prediksi pada menu prediksi penjualan, jika tidak memilih untuk login admin maka user akan bisa memilih menu yang tersedia pada halaman home.

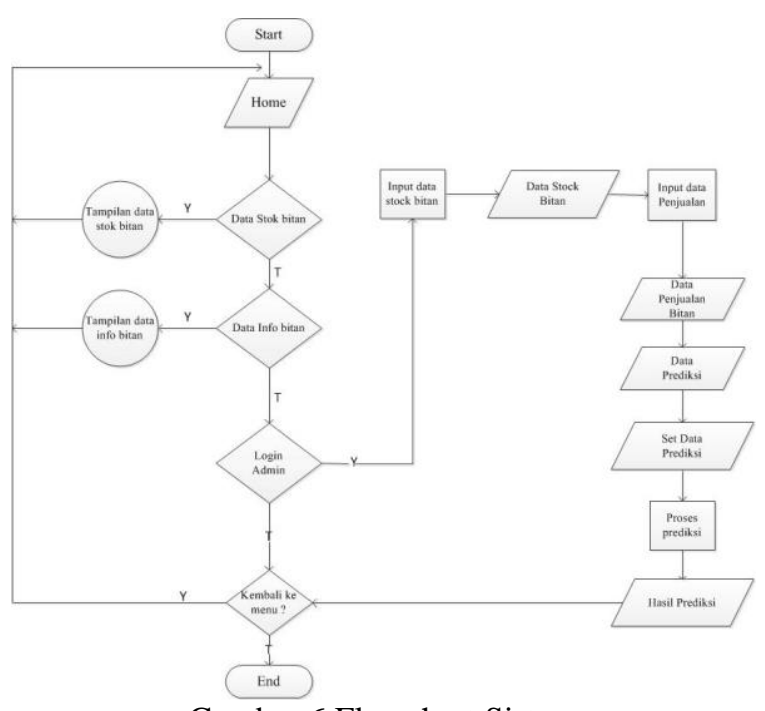

Gambar 6 Flowchart Sistem

\subsection{Tabel Admin}

Menyimpan username dan password yang digunakan untuk login admin, isi dari table admin seperti struktur tabel 1.
Tabel 1 Struktur Tabel Admin

\begin{tabular}{|l|l|l|}
\hline Nama Field & Jenis & Keterangan \\
\hline Id & $\operatorname{Int}(10)$ & Primary \\
\hline username & $\operatorname{varchar}(60)$ & admin \\
\hline password & $\operatorname{varchar}(60)$ & Pass \\
\hline
\end{tabular}

\subsection{Tabel Stock}

Menyimpan data dari stok bibit ikan yang berisikan attribute jenis, umur, ukuran, jumlah, keterangan dan waktu seperti tabel 2 dibawah ini.

Tabel 2 Struktur tabel Stock

\begin{tabular}{|l|l|l|}
\hline Nama Field & Jenis & Keterangan \\
\hline Id & Int(15) & Primary \\
\hline Jenis & Varchar(60) & Jenis Bitan \\
\hline Umur & Varchar(60) & Umur Bitan \\
\hline Ukuran & Varchar(60) & Ukuran Bitan \\
\hline Jumlah & Varchar(60) & Jumlah Bitan \\
\hline Keterangan & Varchar(60) & Keterangan \\
\hline Bulan & Varchar(60) & Info Waktu \\
\hline
\end{tabular}

\subsection{Tabel Penjualan}

Menyimpan data dari penjualan bibit ikan yang berisikan attribute jenis, terjual, harga, bulan,tahun dantotal seperti tabel 3 dibawah ini.

Tabel 3 Struktur Tabel Penjualan

\begin{tabular}{|l|l|l|}
\hline Nama Field & Jenis & Keterangan \\
\hline Id & Int(15) & Primary \\
\hline Jenis & Varchar(50) & Jenis Bitan \\
\hline Terjual & Int(15) & Bitan terjual \\
\hline Harga & Varchar(50) & Harga per bibit \\
\hline Bulan & Varchar(50) & Bulan \\
\hline Tahun & Varchar(50) & Tahun \\
\hline Total & Varchar(50) & Total harga \\
\hline
\end{tabular}

\section{HASIL DAN PEMBAHASAN}

\subsection{Pengujian Aplikasi}

Pengujian komponen dari fitur-fitur yang tersedia pada halaman admin dan user untuk meninjaukan sistem yang saya bangun sudah berjalan sesuai dengan alur sistem yang sudah dibuat, berikut tampilan dari menu-menu yang ada pada halaman web yang saya buat :

\subsection{Halaman home user}

Menampilkan tempat budidaya bibit ikan yang ada pada lokasi ibat pandaan sepergi Gambar 5.

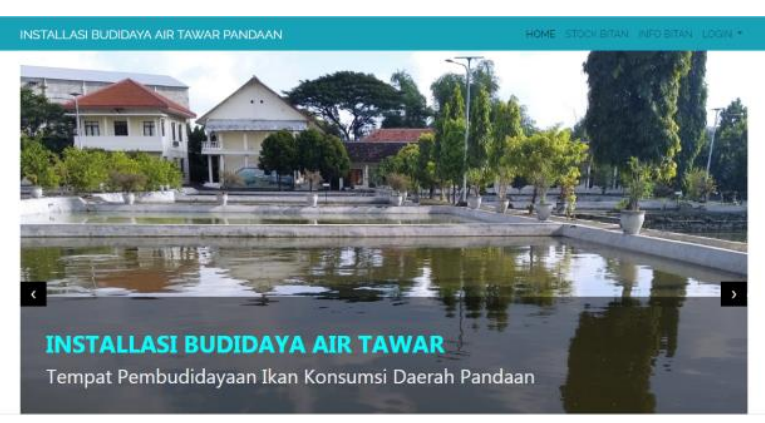

Gambar 5 Menu Home 
Gambar 5 merupakan tampilan dari lokasi pembudidayaan Bibit Ikan Air Tawar yang berada di IBAT Pandaan.

\subsection{Halaman Stock Bitan}

Menampilkan data bibit ikan air tawar yang tersedia pada tempat pembudidayaan ikan air tawar ibat pandaan seperti Gambar 6.

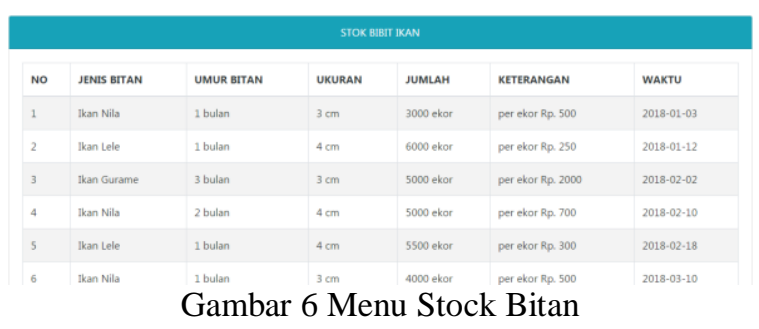

Gambar 6 merupakan tampilan informasi stock bibit ikan air tawar yang tersedia pada lokasi pembudidayaan Bibit Ikan Air Tawar yang berada di IBAT Pandaan.

\subsection{Halaman Info Bitan}

Menampilkan data penjualan bibit ikan setiap tahunnya, data tersebut ditampilkan dengan bentuk chart balok seperti Gambar 7.

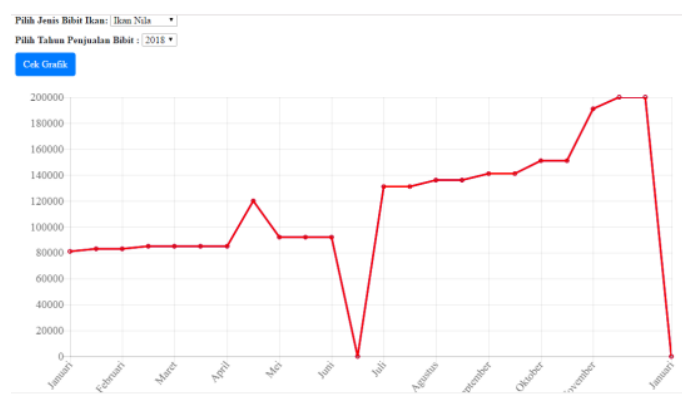

Gambar 7 Info Bitan

Gambar 7 merupakan tampilan informasi bibit ikan air tawar yang tersedia pada lokasi budidaya Bibit Ikan Air Tawar yang berada di IBAT Pandaan.

\subsection{Form Login}

Login user untuk masuk kedalam halaman admin yang memiliki fungsi mengatur dara yang ditampilkan ke halam user dan juga untuk proses prediksi penjualan seperti Gambar 8 .

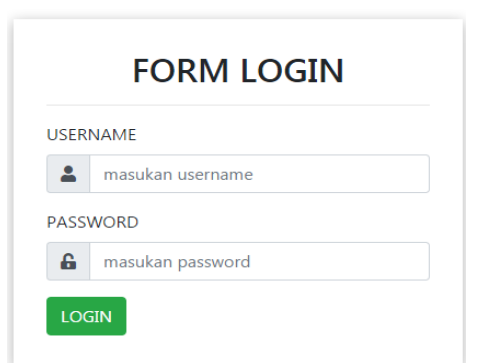

Gambar 8 Login Admin

\subsection{Menu data stok bibit ikan}

Menu data stok bibit ikan dalam sisi admin, didalam ini ada fitur seperti tambah data, edit data dan hapus datastok bibit ikan seperti Gambar 9.

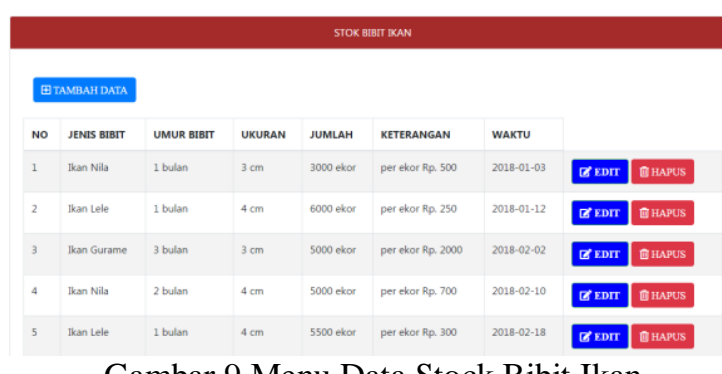

Gambar 9 Menu Data Stock Bibit Ikan

Gambar 6 merupakan tampilan data stock bibit ikan air tawar yang tersedia pada lokasi pembudidayaan Bibit Ikan Air Tawar yang berada di IBAT Pandaan.

\subsection{Menu Data penjualan}

Pada menu data penjualan ini menampilkan inforasi hasil penjual bibit ikan air tawar pada ibat pandaan, data tersebut berupa total bibit ikan terjual dan harga satuan bibit ikan seperti Gambar 10.

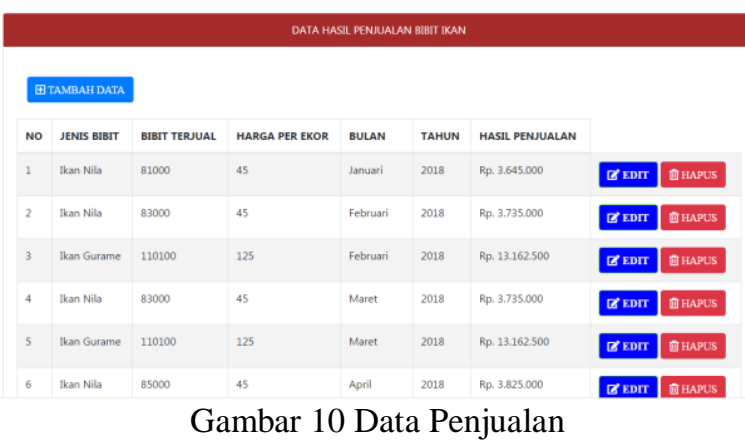

Gambar 10 merupakan tampilan data penjualan bibit ikan air tawar selama 2 tahun terakhir pada lokasi budidaya Bibit Ikan Air Tawar yang berada di IBAT Pandaan.

\subsection{Menu Prediksi Penjualan}

Tampilan dari menu prediksi penjualan yang menggunakan metode trend moment, didalam menu ini menggunakan data penjualan selama dua tahun terakhir sebagai data prediksi seperti Gambar 11.

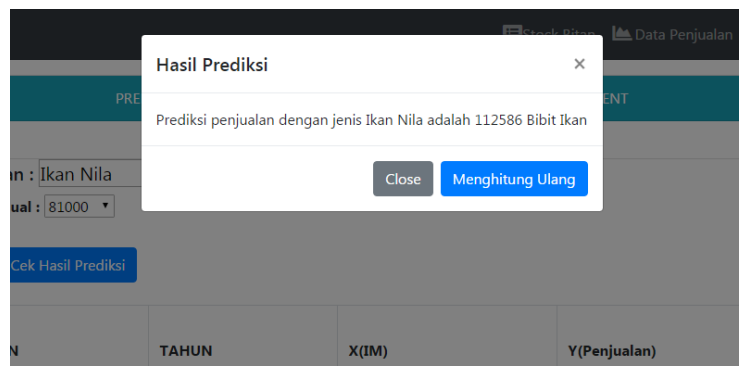

Gambar 11 Menu Prediksi Penjualan 
Gambar 11 merupakan tampilan dari menu prediksi penjualan pada lokasi budidaya Bibit Ikan Air Tawar yang berada di IBAT Pandaan.

\subsection{Penerapan Metode Trend Moment}

Berikut adalah simulasi penghitungan penjualan Bibit ikan Jenis Ikan Nila bulan Januari 2018 sampai dengan Desember 2019 seperti ditunjukkan pada tabel dibawah ini.

Tabel 4 Data penjualan Bibit ikan nila mulai dari Januari 2018 sampai Desember 2019

\begin{tabular}{|l|l|l|l|l|l|}
\hline No. & Jenis & $\begin{array}{l}\text { Terjual } \\
(\mathrm{ekor})\end{array}$ & $\begin{array}{l}\text { Harga } \\
(\mathrm{Rp})\end{array}$ & Bulan & Tahun \\
\hline 1 & Nila & 81.000 & 45 & Januari & 2018 \\
\hline 2 & Nila & 83.000 & 45 & Februari & 2018 \\
\hline 3 & Nila & 83.000 & 45 & Maret & 2018 \\
\hline 4 & Nila & 85.000 & 45 & April & 2018 \\
\hline 5 & Nila & 85.000 & 45 & Mei & 2018 \\
\hline 6 & Nila & 85.000 & 45 & Juni & 2018 \\
\hline 7 & Nila & 85.000 & 45 & Juli & 2018 \\
\hline 8 & Nila & 120.000 & 45 & Agustus & 2018 \\
\hline 9 & Nila & 92.000 & 45 & September & 2018 \\
\hline 10 & Nila & 92.000 & 45 & Oktober & 2018 \\
\hline 11 & Nila & 92.000 & 45 & November & 2018 \\
\hline 12 & Nila & - & - & Desember & 2018 \\
\hline 13 & Nila & 131.000 & 35 & Januari & 2019 \\
\hline 14 & Nila & 131.000 & 35 & Februari & 2019 \\
\hline 15 & Nila & 136.000 & 35 & Maret & 2019 \\
\hline 16 & Nila & 136.000 & 35 & April & 2019 \\
\hline 17 & Nila & 141.000 & 35 & Mei & 2019 \\
\hline 18 & Nila & 141.000 & 35 & Juni & 2019 \\
\hline 19 & Nila & 151.000 & 35 & Juli & 2019 \\
\hline 20 & Nila & 151.000 & 35 & Agustus & 2019 \\
\hline 21 & Nila & 191.000 & 35 & September & 2019 \\
\hline 22 & Nila & 200.000 & 35 & Oktober & 2019 \\
\hline 23 & Nila & 200.000 & 35 & November & 2019 \\
\hline 24 & Nila & - & - & Desember & 2019 \\
\hline
\end{tabular}

Table 5 Data Penjualan Bibit Ikan Nila yang dipengaruhi oleh metode Trend Moment

\begin{tabular}{|l|l|l|l|l|l|}
\hline Bulan & Tahun & $\mathrm{X}$ & $\mathrm{Y}$ & $\mathrm{XY}$ & $\mathrm{X}^{\mathbf{2}}$ \\
\hline Jan & 2018 & 0 & 81.000 & 0 & 0 \\
\hline Feb & 2018 & 1 & 83.000 & 83.000 & 1 \\
\hline Mar & 2018 & 2 & 83.000 & 166.000 & 4 \\
\hline Apr & 2018 & 3 & 85.000 & 255.000 & 9 \\
\hline Mei & 2018 & 4 & 85.000 & 340.000 & 16 \\
\hline Juni & 2018 & 5 & 85.000 & 425.000 & 25 \\
\hline Juli & 2018 & 6 & 85000 & 510.000 & 36 \\
\hline Agu & 2018 & 7 & 120000 & 840.000 & 49 \\
\hline Sep & 2018 & 8 & 92000 & 736.000 & 64 \\
\hline Okto & 2018 & 9 & 92000 & 828.000 & 81 \\
\hline Nov & 2018 & 10 & 92000 & 920.000 & 100 \\
\hline Des & 2018 & 11 & - & - & 121 \\
\hline Jan & 2019 & 12 & 131000 & 1572000 & 144 \\
\hline Feb & 2019 & 13 & 131000 & 1703000 & 169 \\
\hline Mar & 2019 & 14 & 136000 & 1804000 & 196 \\
\hline April & 2019 & 15 & 136000 & 2040000 & 225 \\
\hline Mei & 2019 & 16 & 141000 & 2256000 & 256 \\
\hline Juni & 2019 & 17 & 141000 & 2397000 & 289 \\
\hline Juli & 2019 & 18 & 151000 & 2718000 & 324 \\
\hline Agu & 2019 & 19 & 151000 & 2869000 & 361 \\
\hline
\end{tabular}

\begin{tabular}{|l|l|l|l|l|l|}
\hline Sep & 2019 & 20 & 191000 & 3820000 & 400 \\
\hline Okto & 2019 & 21 & 200000 & 4200000 & 441 \\
\hline Nov & 2019 & 22 & 200000 & 440000 & 484 \\
\hline Des & 2019 & 23 & - & - & 529 \\
\hline Total & & 276 & 2692000 & 34982000 & 4324 \\
\hline Rata2 & & & 112166.7 & & \\
\hline
\end{tabular}

Berdasarkan data yang diperoleh pada table diatas, maka untuk memprediksi bulan januari 2020 dengan cara memperoleh nilai a dan b dengan sebagai berikut :

$$
\begin{aligned}
& \mathrm{b}=\frac{\mathrm{n}\left(\sum \mathrm{xy}\right)-\left(\sum \mathrm{x}\right)\left(\sum \mathrm{y}\right)}{\left(\sum \mathrm{x}^{2}\right)-\left(\sum \mathrm{x}\right)^{2}} \\
& \mathrm{~b}=\frac{96576000}{276000}=3499.130435 \\
& \mathrm{a}=\frac{\sum \mathrm{y}-\mathrm{b}\left(\sum \mathrm{x}\right)}{\mathrm{n}} \\
& \mathrm{a}=\frac{1726240}{24} \quad=71926.66667
\end{aligned}
$$

Setelah nilai a dan b ditemukan, kemudian mencari nilai trend januari 2020 dengan $X=24$, seperti dibawah ini

$$
\begin{aligned}
\mathrm{Y} & =\mathrm{a}+\mathrm{bX} \\
\mathrm{Y} & =71926.66667+3499.130435(24) \\
& =155905.8
\end{aligned}
$$

Langkah selanjutnya setelah nilai peramalan ditemukan, mencari nilai index musim maka akan diperoleh perhitungan sebagai berikut :

Indeks musim $=\frac{\text { rata-rata permintaan bulan tertentu }}{\text { Rata-rata permintaan bulanan }}$

Penjabaran :

Rata-Rata permintaan bulan tertentu $=81.000$

Rata-Rata Permintaan bulanan $=112166.7$

Index Musim $=0.72214$

Hasil dari ramalan akhirdengan metode trend moment setelah dipengaruhi oleh indeks musim maka akan menggunakan perhitungan sebagai berikut:

$$
\begin{aligned}
& Y^{*}=\text { Indeks Musim } \times Y \\
& Y^{*}=0.72214 \times 155905.8=112586
\end{aligned}
$$

Jadi peramalan bulan Januari 2020 untuk Bibit Ikan Nila yang dipengaruhi oleh indek musim sebesar 112586 Bibit ikan.

\subsection{Pengujian Metode}

Dalam proses pengujian metode menggunakan data hasil prediksi sistem dengan Microsoft Exel sebagai media perhitungan manual, hasil dari proses perhitungan manual akan dibandngkan dengan hasil proses perhitungan sistem yang ada pada website. Setelah proses perbandingan data selesai terdapat beberapa data penjualan mengalami kenaikan data cukup tinggi, kenaikan data 
tersebut hingga 19\% dari data penjualan bibit ikan pada tahun 2019, data tersebut bisa dilihat pada tabel 4.3.

Tabel 4.3 Hasil perbandingan

\begin{tabular}{|c|c|c|c|c|c|}
\hline No & Jenis & $\begin{array}{c}\text { Bln } \\
2019\end{array}$ & $\begin{array}{c}\text { Data } \\
\text { Real }\end{array}$ & $\begin{array}{c}\text { Hasil } \\
\text { Sistem }\end{array}$ & $(\%)$ \\
\hline 1 & Nila & Jan & 131.000 & 134718 & $2.8 \%$ \\
\hline 2 & Nila & Feb & 131.000 & 152612 & $16.5 \%$ \\
\hline 3 & Nila & Mar & 136.000 & 157345 & $15.7 \%$ \\
\hline 4 & Nila & Apr & 136.000 & 161956 & $19.1 \%$ \\
\hline 5 & Nila & Mei & 141.000 & 159253 & $12.9 \%$ \\
\hline 6 & Nila & Jun & 141.000 & 155663 & $10.4 \%$ \\
\hline 7 & Nila & Jul & 151.000 & 150765 & $0.15 \%$ \\
\hline 8 & Nila & Agu & 151.000 & 155330 & $2.8 \%$ \\
\hline 9 & Nila & Sep & 191.000 & 200328 & $4.9 \%$ \\
\hline 10 & Nila & Okt & 200.000 & 199288 & $0.35 \%$ \\
\hline 11 & Nila & Nov & 200.000 & 197189 & $1.4 \%$ \\
\hline 12 & Nila & Des & - & 134718 & - \\
\hline
\end{tabular}

Pada tabel 4.3 terdapat data hasil perbandingan penjualan bibit ikan air tawar yang memakai data hasil prediksi sistem dengan perhitungan manual pada Microsoft Exel, data yang diperoleh menunjukkan tingkat persentase kesalahan paling tinggi dalam angka $19.1 \%$, hal yang menyebabkan tingginya persentase kesalahan diakibatkan oleh faktor penambahan data baru yang signifikan hingga lebih dari $50 \%$ dari data penjualan tahun lalu. Dalam proses prediksi bias mendapat data penjualan lebih akurat jika data yang diolah lebih banyak

\section{KESIMPULAN DAN SARAN \\ 5.1 Kesimpulan}

Berdasarkan dari hasil perancangan dan implementasi sistem prediksi penjualan bibit ikan pada ibat pandaan dapat disimpulkan sebagai berikut yaitu :

1. Aplikasi yang dibuat penerapan metode trend moment untuk menghitung prediksi penjualan bibit ikan pada instalasi budidaya air tawar pandaan adalah berbasis pada website.

2. Hasil pengujian fungsional dilakukan dengan menggunakan 3 browser yaitu Google Chrome, Mozilla Firefox dan UC Browser memiliki hasil sesuai harapan.

3. Data yang didapatkan dari pengujian metode menunjukkan tingkat kesalahan sistem mencapai 19\%, hal ini disebabkan oleh tingginya angka penambahan data baru melebihi angka penjualan tahun lalu hingga $50 \%$. Oleh karena itu perlu penambahan metode untuk mendapatkan data prediksi yang lebih akurat karena hasil prediksi menggunakan metode trend momend masih diatas $10 \%$.

4. Berdasarkan hasil pengujian user menunjukkan bahwa persentase Sangat Baik hingga 30\%, Baik mencapai 38\%, Cukup mencapai $28 \%$ dan Kurang hingga $1 \%$, Hasil ini didapat dari pengujian 12 user dengan total 18 pertanyan yang dibagi menjadi 5 bagian yakni Homepage, Stok Bitan, Info Bitan, usability dan readibility.

\subsection{Saran}

Agar dalam aplikasi ini berjalan dengan baik kedepannya, maka ada beberapa hal yang perlu dilakukan yaitu sebagai berikut:

1. Perlu penambahan data penjualan secara berkala untuk mendapatkan hasil prediksi yang lebih akurat.

2. Penambahan jenis bibit ikan untuk di prediksi agar hasil prediksi penjualan lebih variatif.

3. Penambahan variable atau jenis ikan untuk proses prediksi seperti penjualan ikan konsumsi agar aplikasi ini tidak hanya terbatas pada menghitung prediksi penjualan pada bibit ikan..

\section{DAFTAR PUSTAKA}

[1] Wahyudi Imam Penerapan Metode Trend Moment Untuk Peramalan Penjualan Sepatu Dan Sandal Pada Toko BATT. Kediri : Universitas Nusantara PGRI Kediri.

[2] Aryanto Rudy, Triswidananta Desta Odithiya, Pangestu Rukma Bagas. Sistem Peramalan Persediaan Obat Kronis Menggunakan Metode Trend Moment Malang, Politeknik Negeri Malang

[3] Kusrini, Budi Utami Dias Ayu. Rancang Bangun Sistem Peramalan Penjualan dan Pengendalian Persediaan Beras Menggunakan Metode Trend Moment, Yogyakarta: STMIK AMIKOM Yogyakarta

[4] Fuad Nurul dan Sulistiono Eko. 2016 . Prediksi Penjualan Kerudung Rabbani di Griya Muslim Store Dukun Gresik Dengan Metode Trend Moment, Lamongan: Universitas Islam Lamongan. 49-53

[5] Mujilahwati Siti, Nawafilah Qomariyah Nur, Aliyudin Muhammad . 2019 . Analisis Hasil Prediksi Dengan Metode Promethee, Lamongan Vol.2, No.1: Universitas Islam Lamongan. 35-40

[6] Sudarso nono, Suciyona Nanang dan Hardianto Riyan, 2016 , Sistem penunjang keputusan budidaya ikan air tawar di Giri Tirta Cikalang, Yogyakarka, STMIK AMIKOM Yogyakarta

[7] Dergibson S, dan Sugiarto, 2002, Metode Statistika Untuk Bisnis dan Ekonomi, Jakarta : PT. Gramedia Pustaka Utama. Halaman 208-217

[8] Evander Lay Mario, 2017, E-Commerce akustik dan sparepart kota malang menggunakan metode customer to customer, Malang : Institut Teknologi Nasional Malang. Volume 1 No. 2

[9] Prasetyo Didik D, 2016 , pemograman PHP, ELEX MEDIA KOMPUTINDO, Jakarta.

[10] Solichin Achmad, 2016 , pemograman web dengan PHP MySql, Universitas Budi Luhur, jakarta. 